\title{
クロムおよびクロム基耐熱合金
}

\section{吉 田進・大庭幸 夫*}

\section{1 緒言}

クロム基耐熱合金が注目されたのは，第 2 次大戦中米国に括い てコバルト基耐熱合金にまさる強力な耐熱合金を見出すためと， ニッケル，コパルト等の耐熱材料資源の欠乏に対処してそれを節 約して比較的安価な金属で置きかえた合金を開発する必要があっ た事情から，金属クロムが高温ですぐれた耐酸化性と強さを持っ ていることに着目して，研究に着手したことに始まる。この研究 は Parke, Bens') によって行なわれ, $60 \mathrm{Cr}-25 \mathrm{Mo}-15 \mathrm{Fe}$ を基 本成分とする合金は，非常にすぐれた高温抗クリープ性を持って いることがわかったけれども，その反面室温では極めて脆く，と

らてい実用材料とはなり得なかった。

その後, 1950 年以後 Sully, Gilbert, Wain2〜4) らによって, 純クロムの脆さについての研究が活発に行なわれ，クロムの脆さ はクロムの本質的性質でなく，含有されている不純物の影響であ って，純度を向上させれば室温でもかなり靶性を現わすようにな ることが見出された。特に Wain はクロムの脆性とガス不純物の 関係をくわしく調べた結果，最も有害な不純物は微量に含まれて いる窒素であって，この有害な窒素の影響を何らかの方法で除く ことによって，クロムの脆さは著しく改善でさることを報告し， クロム括よびその合金の将来性について，明るい望みを与えてい る。

そこでこの総説では，純クロムおよびクロム基耐熱合金の脆性 とその改善を主題として, 最近の研究をとりまとめた。

\section{2 純 口 4}

\section{$2 \cdot 1$ 製 法}

金属クロムの工業的製法には，従来酸化クロムをアルミニウム で還元する Aluminothermic Process が用いられていたが， 得 られた金属の純度はあまり良好とはいえず， $\mathrm{Al}, \mathrm{Fe}, \mathrm{Si}$ 等を相 当多量に含有している。ここで比較的最近行なわれている純度の 高いクロムを得る二, 三の代表的な方法について述べ，あわせて 純度を表 1 に示した。

$2 \cdot 1 \cdot 1$ クロムミョウバン浴電解法 この方法は ${ }^{5,6)}$, 高崖素フ ェロクロムを硫酸で溶解処理したのち，浄液作業によって， $\mathrm{Cr}_{2}$. $\left(\mathrm{SO}_{4}\right)_{3} \cdot\left(\mathrm{NH}_{4}\right)_{2} \mathrm{SO}_{4}$ を主体とする電解液を精製し，隔膜を有する 循環式電解槽を用いて金属を電着させる方法である。この方法は 純度の点では, 後記のクロム酸浴を用いた場合に比較するとやや 劣るが，安価な原材料から比較的純度の高い金属を得ることがで

* 科学技術庁金属材料技術研究所第 7 部: 東京都目黑区中目黑.
きると同時に，電流効率の良好な 3 価浴を使用するため，クロム 酸浴電解法の場合にくらべて数分の一の電力消費ですみ，工業的 採算に応じ得ることを特徽としている。

$2 \cdot 1 \cdot 2$ クロム酸浴電解法，クロム酸浴から金属を電解採取す る方法である7)。得られた金属には，0.1〜0.05\% の酸素および $0.003 \%$ 程度の窒素を含むほかは，他の非金属，金属不純物含量 は極めて微量含まれるにすぎない。この電解法の欠点は，電流効 率が低く，僅かに 10\% を越える程度にすぎないので，工業的規 模の生産に移すことの困難さにあった。最近米国のBureau of Mines ではクロム酸浴に適当な添加剤を加えて電流効率を増す 試みがなされ，ある程度の成果を収めたとの報告がある。又 この電解金属はアーク溶解後, 適当な加工法によって, 板または 線に加工できる。

$2 \cdot 1 \cdot 3$ ヨウ素法 高純度チタン, ジルコニウムなどの精製に 用いられる方法であるが，クロムの場合ヨウ化クロムが比較的蒸 発しにくいため, 反応容器の温度をチタン，ジルュニウムの場合 より高くせねばならない(約 $800^{\circ} \mathrm{C}$ )。従って大量生産のため金 属製容器を使用する時は, 特に耐食性の問題を考えねばならない といら不利益がある。しかし得られた金属は表に示したように極 めて純粋である。

な括このほかにソ連邦では, 真空蒸留法によってクロムの精製 を行なっているとの報告がある8)。

\section{$2 \cdot 2$ 溶解之加 工}

クロムの溶融点は約 $1900^{\circ} \mathrm{C}$ といわれ9)，溶融状態では極めて 活性で, 酸素, 窒素とはもちろん, ほとんどすべてのルッボ耐火 物とも反応する。そしてこのような溶解の際に入る不純物は，鋳 塊の熱間加工性を著しく損 ら。また酸素, 窒素は熱間加工の温度 でも試料表面を侵し，龟裂発生の原因となり易いので，加工には 特殊の方法が採用されている。

$2 \cdot 2 \cdot 1$ 溶解 非消耗タングステン電極, 水冷式銅ルツボを用 いて，アルゴンガス中でアーク溶解する。溶解がアルゴンガス中 で行なわれるため鋳塊にはブローホールができやすく，こわを除 くため真空アーク溶解が望ましいのであるが，クロムの蒸気圧が 高いためアークが安定せず，困難と考えられている。しかし減圧 溶解は試みられ10)，効果をあげている。

$2 \cdot 2 \cdot 2$ 加工 クロム酸浴電解法から得られた程度の純度を持 った純クロムでも，熱間加工は容易でない。筆者らの経験では， 鋳塊の粗い鋳造組織を重裂を生じさせないでこわすためには，加 工温度，丕速度，試料表面の污染等に細心の注意を执わねばなら ぬが，特に最初の鋳造組織をこわす鍛造は大切で，この工程でう

\begin{tabular}{|c|c|c|c|c|c|c|c|c|c|c|c|c|c|}
\hline & $\mathrm{O}$ & $\mathbf{N}$ & $\begin{array}{cc}\text { 表 } & 1 \\
\mathrm{~s} & \end{array}$ & $\begin{array}{ll}\text { 各 } & \text { 種 } \\
\mathrm{C} & \end{array}$ & $\begin{array}{l}7 \\
\mathrm{P}\end{array}$ & $\begin{array}{l}\text { 厶 } \\
\mathrm{Cu}\end{array}$ & $\begin{array}{l}\text { の } \\
\mathrm{Zn}\end{array}$ & $\begin{array}{c}\text { 化 学 } \\
\mathrm{Pb}\end{array}$ & $\begin{array}{c}\text { 組 成 } \\
\mathrm{Fe}\end{array}$ & $\begin{array}{r}(w t \%) \\
\text { Si }\end{array}$ & Al & $\mathrm{W}$ & $\mathrm{Zr}$ \\
\hline テルミット法 & 0.20 & 0.17 & 0.05 & $<0.05$ & $<0.05$ & & & & $<0.05$ & $<0.5$ & $<0.8$ & & \\
\hline クロムミョウバン浴電解法 & $<0.55$ & $<0.03$ & 0.03 & 0.02 & 0.001 & 0.001 & $\operatorname{tr}$ & 0.003 & 0.2 & 0.01 & 0.01 & & \\
\hline $\begin{array}{l}\text { クロム酸浴電解法 } \\
\text { ヨ ウ 采 法 }\end{array}$ & $\begin{array}{l}0.09 \\
0.0005\end{array}$ & $\begin{array}{l}0.004 \\
0.0005\end{array}$ & $\begin{array}{l}0.002 \\
0.0003\end{array}$ & $\begin{array}{c}0.002 \\
0.001 \sim 0.004\end{array}$ & $\begin{array}{c}<0.001 \\
0.0002\end{array}$ & $\begin{array}{r}<0.001 \\
0.002\end{array}$ & & $\operatorname{tr}$ & $\begin{array}{l}<0.001 \\
\text { detected }\end{array}$ & $\begin{array}{c}<0.001 \\
\text { not detected }\end{array}$ & $<0.001$ & & \\
\hline 真空洆留法 & 0.01 & 0.007 & & 0.005 & & $<0.002$ & & & 0.012 & 0.001 & $0.001 \mathrm{no}$ & detected & not detected \\
\hline
\end{tabular}


まく鋳造組織をこわし てしまうと，その後の 加工は容易となる。

Wain もこの最初の 鍛造"1)を重視して，据 込鍛造を推奖してい る。まず始めに，鋳塊 を $1200^{\circ} \mathrm{C}$ で焼鈍して,

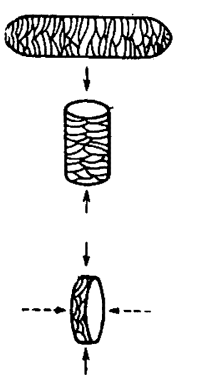

(a)

(b)
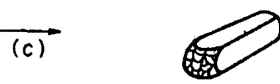

軟鋼もしくは不銹鋼の シースに封じ込めて, 図1のよ5に $900^{\circ} \mathrm{C} て ゙$ 鉎造の最初の打撃を， 鋳塊の柱状晶組織に対 して直角方向に加える

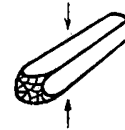

$\overrightarrow{(d)}$

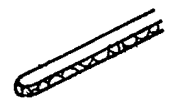

図 1 純クロムインゴットの鍛造の各段 階に扣ける打撃の方向と柱状晶の関係 方法である。彼はこのやり方で, 鍛造初期に発生し易い龟裂の防 止に効果があったと述べている。

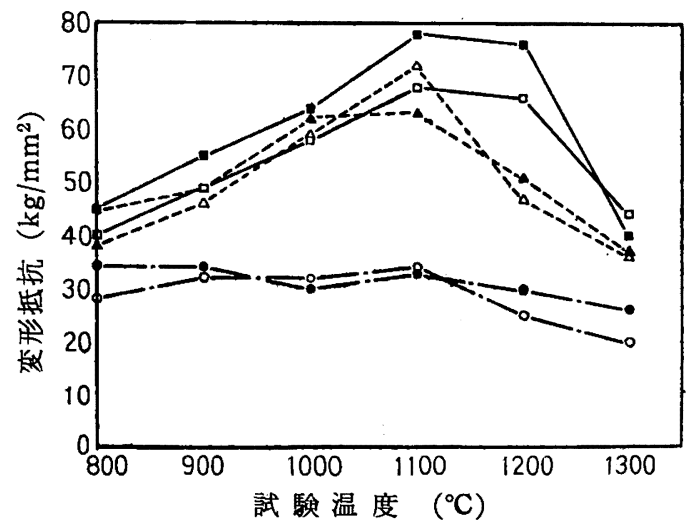

図 2 各種ク口ムの変形抵抗

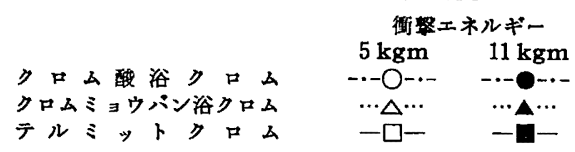

また図 $2^{12)}$ はクロム酸浴電解クロム，3 洒浴電解クロム，テル ミットクロムを用いて，800 $1200^{\circ} \mathrm{C}$ の間の変形抵抗を両振子式 鍛造試験機によって測定した結果で，これによると３価浴ク口 ム, テルミットクロムの変形抵抗は，この温度範围では，クロム 酸浴クロムの変形抵抗にくらべてかなり高くなっていることと， $1100^{\circ} \mathrm{C}$ 付近でク口ム酸浴クロムには見られない変形抵抗の著し いピークを生じていることがわかる。前者の影響は不純物含量の 差が総合的に現われた結果であり, 後者は試料に含まれている窒 素の影響であると推定されている。そして亀裂の入り方は，ピー ク付近の温度を境として, 低温側では粒内破断であるが, 高温側 では粒界破断へと変化する。しかし酸素含量は $0.3 \%$ 以下では加 工性に有害な影響は与えないと考えられている。

\section{$2 \cdot 3$ 機 械 的 性 算}

現在の純クロムについての研究は,クロムの室温に特ける脆ざ の原因を明らかにすることと，その脆さを改善する方法を見出す ことに重点が沶かれている。

数年前まで純クロムは室温で脆く，特に再結晶された状態で は, たとえヨウ素法クロム程度の高純度クロムでさえも極端に脆 いため，実用材料として使用することに疑問がもたれていた。そ してこのような脆さを改善するために始めになされたことは， Sully ${ }^{18)}$ および Maykuth ら ${ }^{14)}$ が行なったように，純クロムに各
種の少量の元素を加えて，選移温度を下げよ5とする試みであっ た。添加元素がクロムの脆さに与える影響は複雑であるが，結論 的には彼らが最初期待したよ5な，遷移温度を下げるために著し く効果のある添加元素は見つからなかった。

Wain ${ }^{15)}$ はこの脆さについて詳しく検討した結果，クロムの靱 性は純度，組織，試料の表面粗さ等に钽感に影響されるが，ク口 ム地中に固溶されている窒素が脆性をもたらす主原因であるとし， 窒素原子がいわゆるコットレル雾团気をつくって，転位の運動を 阻止するためであると述べている。眓３は加工を受けたクロムが 再結晶されて行くにつれて，次第にその䩒性を失って行く過程を 示したものである。

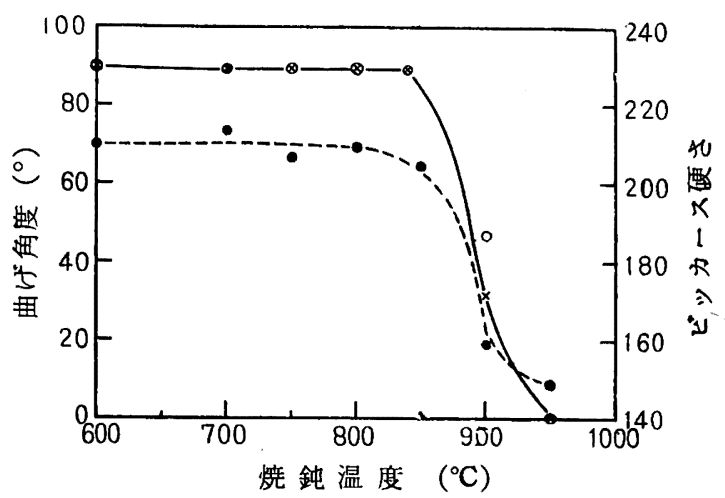

図 3 室温靶性に括よぼす再結晶の影響

○電解研磨した試料 メ エッチした武料 ・ ビッカース硬さ

しかしながら，このよ5な窒素原子の転位の固着作用にもとつ く脆さを改善するための研究も進められており，かなりの成果を おさめている。すなわち Wain は㳄鋼シースに緊密に封じ込めた 試料を $1200^{\circ} \mathrm{C}$ で焼鈍して，室温まで徐冷してからシースをはく 離して取り出したクロムは，かなり靶性を示すようになり，僄移 温度は約 $300^{\circ} \mathrm{C}$ から $-100^{\circ} \mathrm{C}$ まで下がるといっている。

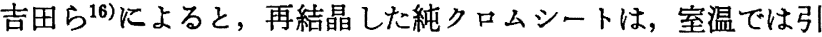
張り試験を行なっても全く脆くて，伸びは認められないが，この 試料を $400 \sim 500^{\circ} \mathrm{C}$ の間で適量の軽加工を与えると， $40 \%$ 以上の 伸びを示すよ5になる。図 4 はこの Prestrainの効果を現わした もので，これはクロム地中に固溶されている絰素原子が Prestrain によって, 安定な窒化物として析出し, 地中の窒素濃度は減 少し，しかも析出物の大きさと分布の状態が適当で転位の運動を 妨害しないため，クロムが鞄性を示すようになったのであろらと 推定されている。

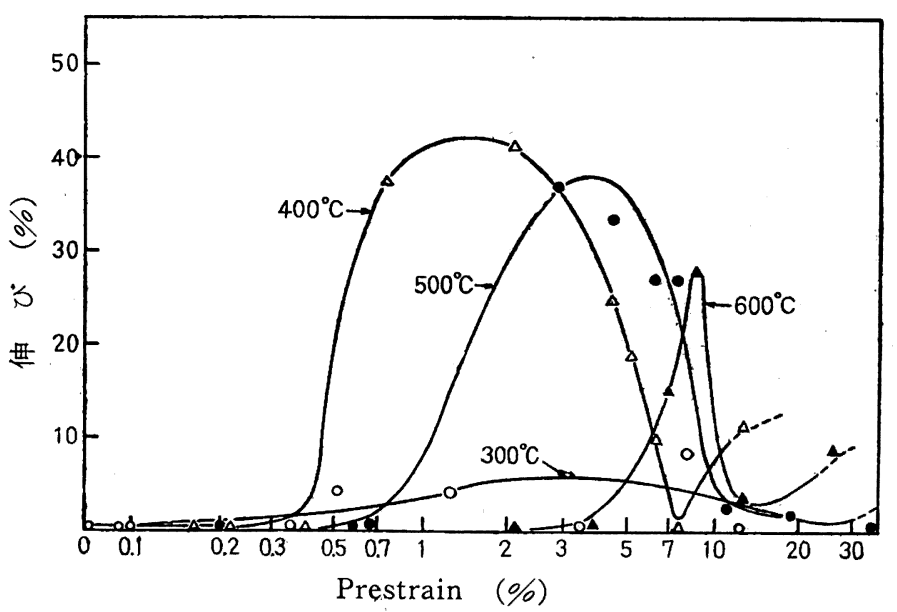

図4 純クロムの勒性に括よぼすPrestrainの効果 


\section{3 クロム基耐熱合金}

\section{1 $\mathbf{C r}-\mathbf{M o}-\mathrm{Fe}$}

耐熱合金として必要な一般的性質は，高温度で長時間の使用に 耐えるため抗クリープ性が大きく，耐酸化性が良好であること と, 熱間加工, 機械切削等が可能な程度の啜性を持っていること である。

$60 \mathrm{Cr}-25 \mathrm{Mo}-15 \mathrm{Fe}$ 合金は 1943 1950 年に Parke, Bens 抒 よび Havekotte らの一連の研究によって発見された合金で，高 温抗クリープ性, 耐酸化性についてはすぐれた性能を持ってい る。このことは図 5 によく示されている。図 5 からわかることは

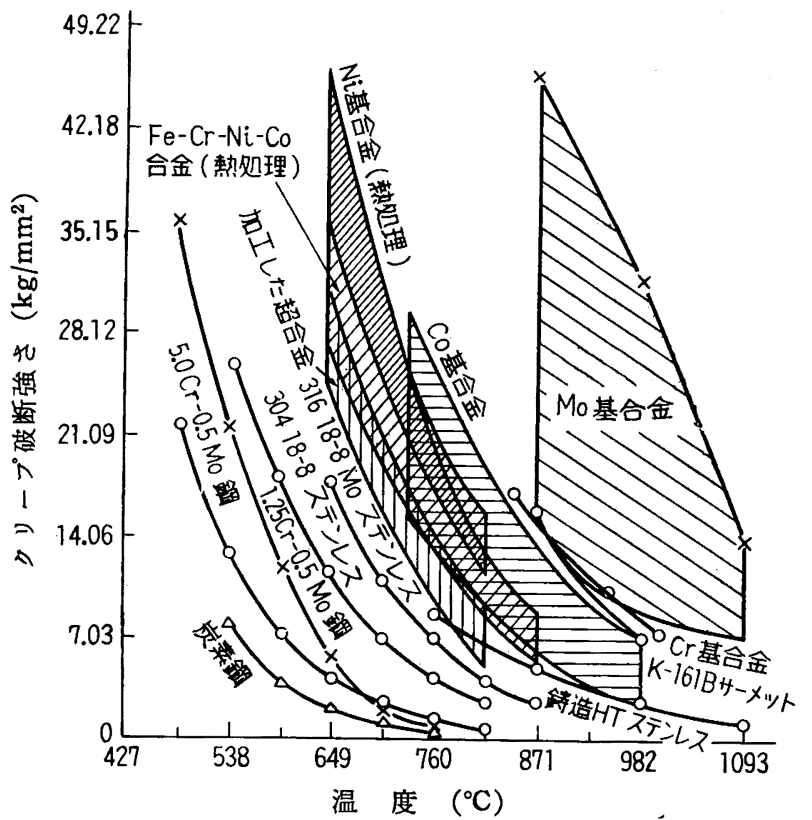

図 5 各種合金の 1000 時間クリープ破断強さ

Mo および Mo 基合金は最も抗クリープ性が大で, $900^{\circ} \mathrm{C}$ 以上の 温度で使用に供し得る。しかし，この合金は極めて耐酸化性に之

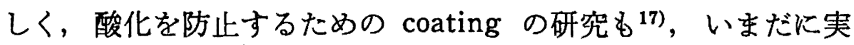
用化の段階に達していないよ5である。次に高性能合金として示 されているのが， $\mathrm{Cr}-\mathrm{Mo}-\mathrm{Fe}$ 系クロム基合金であって，現在最強 の性能を持つと目されているコバルト基, ニッケル基合金をしの ぐクリープ破断強度を持っている。表 2 には代表的ク口ム基合金 組成とクリープ破断強度を掲げた。

表 $260 \mathrm{Cr}-25 \mathrm{Mo}-15 \mathrm{Fe}$ 系クロム基合金

\begin{tabular}{|c|c|c|c|c|c|c|c|c|c|c|}
\hline \multirow{2}{*}{ 合 金 } & \multicolumn{8}{|c|}{ 組 成 (wt\%) } & \multirow{2}{*}{$\begin{array}{c}\text { クリーブ破断強さ } \\
\left(\mathrm{kg} / \mathrm{mm}^{2}\right) \\
100 \mathrm{hr}\end{array}$} & \multirow{2}{*}{$\begin{array}{l}870^{\circ} \mathrm{C} \\
1000 \mathrm{hr}\end{array}$} \\
\hline & c & Mn & $\mathrm{Si}$ & $\mathrm{Cr}$ & Mo & W & $\mathrm{Fe}$ & $T \mathbf{i}$ & & \\
\hline CW 382 & - & - & - & 60 & - & 20 & 20 & - & 16.9 & - \\
\hline CM 469 & 0.05 & - & - & 60 & 25 & - & 15 & - & 24.6 & 14.8 \\
\hline CM 554 & 0.30 & - & - & 60 & 15 & - & 25 & - & 14.1 & - \\
\hline CMT & 0.10 & 0.50 & 0.60 & 58 & 25 & - & 15 & 20 & 32.3 & 26.0 \\
\hline
\end{tabular}

このなかでとりわけチタンを含有した合金は, 非常にすぐれた 性能を持っているが，惜しいことに $870^{\circ} \mathrm{C}$ のクリープ破断試験に おいても，伸びは数％程度にすぎず，室温では極端に脆くて加 工切削も全く困難であった。そしてこの系合金の研究は，その後 次第にとの脆さを改善する方向へと進められた。

\section{$3 \cdot 2$ 高純度クロムを用いた高クロム合金}

前節で述べた $\mathrm{Cr}-\mathrm{Mo}-\mathrm{Fe}$ 系合金の脆さのおもな原因として考 えられたことは, 当然合金の基礎となるクロム自体が脆いために 合金が脆性を示すということであって，米国の Battelle Memọ-

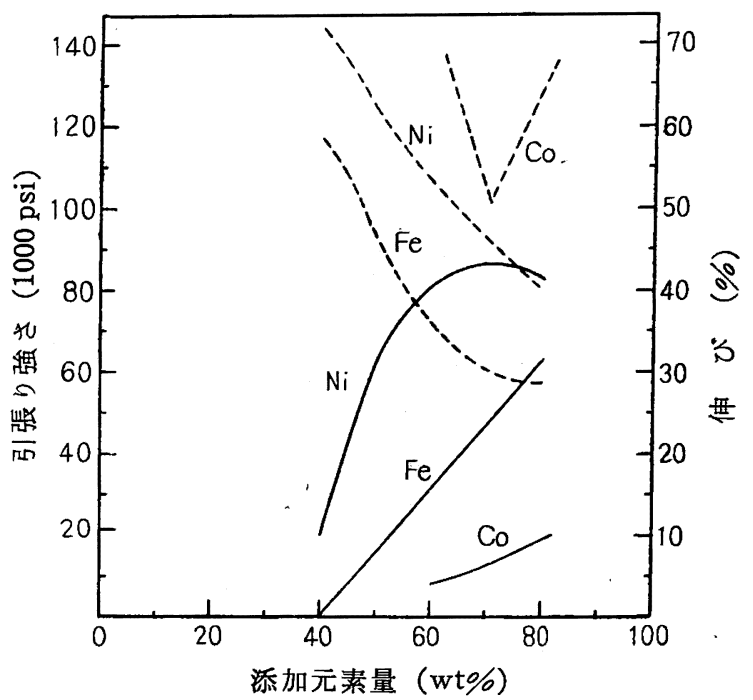

図 6 高純度クロムの機械的性質に括よぼす添加元素の影留 ——張り強さ 一伸び

rial Institute では, 合金の基礎金属として, 純度の高いヨウ素 クロムを用いて, $\mathrm{Cr}-\mathrm{Fe}, \mathrm{Cr}-\mathrm{Ni}, \mathrm{Cr}-\mathrm{Co}$ 系合金について，室温 に拈ける脆性がどのように改善されるかについて研究した ${ }^{18)} 。$

図 6 は合金元素の含量の変化に対応する引張り強度および伸び を示したもので, $\mathrm{Cr}-\mathrm{Ni}, \mathrm{Cr}-\mathrm{Fe}$ 系合金は相当伸びを持ってお り，特に $\mathrm{Cr}-\mathrm{Ni}$ 系合金はすぐれた室温強度と勒性の組合せを持 っていることがわかる。また熱間加工性についても， $\mathrm{Cr}-\mathrm{Fe}$ 系合 金では 76\% Cr 合金まで，また $\mathrm{Cr}-\mathrm{Ni}$ 系合金では $63 \% \mathrm{Cr}$ 合 金まで圧延可能であると報告されている。

さらにオーストラリヤの Defence Standard Laboratory では, 純クロムに少量の添加元素を加えた場合の高温性質を調べた結 果, $10 \% \mathrm{~W}$ および $5 \% \mathrm{Mo}$ を含むクロム合金の $950^{\circ} \mathrm{C}$ における 抗クリープ性, 耐酸化性はともに非常に良好であることを見出し た ${ }^{19)}$ (表 3 参照)。

表 3 純クロムおよび $10 \% \mathrm{~W}, 5 \% \mathrm{Mo}$ 合金

\begin{tabular}{|c|c|c|c|c|c|}
\hline 合 金 & $\begin{array}{l}\text { 応 力 } \\
\left(t / i n^{2}\right)\end{array}$ & $\begin{array}{l}\text { 最小クリープ速度 } \\
\left(\text { in } / \text { in } / \mathrm{hr} \times 10^{4}\right)\end{array}$ & $\begin{array}{c}\text { 第3期クリー } \\
\text { プまの時間 } \\
\text { (hr) }\end{array}$ & $\begin{array}{c}\text { 破断時間 } \\
(\mathrm{hr})\end{array}$ & $\begin{array}{l}\text { 伸 び } \\
(\%)\end{array}$ \\
\hline $\mathrm{Cr}$ & 3 & 3.2 & 84 & 185 & 27 \\
\hline $\mathrm{Cr}-10 \% \mathrm{~W}$ & 6 & 0.68 & 195 & 293 & 4 \\
\hline $\mathrm{Cr}-5 \% \mathrm{Mo}$ & 6 & 0.90 & 120 & 365 & 8 \\
\hline
\end{tabular}

そしてこれらの合金は，抗クリープ性においても，あるいは耐 酸化性に㨟いても，ニッケル基，コバルト基耐熱合金をしのいで おり，この研究所では $\mathrm{Cr} \alpha$ 相のすぐれた高温特性を利用した 超耐熱合金の将来について非常に興味を示しているようである。

\section{4 結言}

以上純クロムおよびクロム基耐熱合金の最近の研究について概 説した。クロム基耐熱合金は十数年も以前から，コバルト基， = ッケル基合金に代わる新合金として注目を集めていたにもかかわ らず, 現在なおも実用に供されていないのが実情である。一般にこ の系の合金の耐熱性は，クロム含量が増加すればするほど良好に なるに反して, その靱性は急速に失われて行くという難点がある。

そして前に述べたように，この脆さはクロム自体の脆さが大部 分の原因をなすものであるから，十分勒性を持った純ク口ムを安 価に供給し得る精鍊法の研究は, 今後も是非行なわなければなら ない。そしてもろ一つの問題は，溶解，鋳造技術であろうかと思 
われる。つまりクロム基合金は溶融点が著しく高く，むるものは $1800^{\circ} \mathrm{C}$ 近くにも達する。それ故に拈そらく従来の耐火物ルツボ を使用した高周波溶解は，クロム基合金の溶解に最良の方法とは いえないと考えられるので，たとえばスカル溶解，鋳造等の新し い技術がさらに進歩して，溶融金属を污すことなく，健全な鋳塊 をつくることができるような技術的な開発がなされることが必要 であろら。

要するに，クロム基耐熱合金が初め期待されたよ5に実用化さ れるためには，今後高純度クロムを安価に製造する方法の発達 と, 溶解, 鋳造, 加工等の技術的進歩が前提条件となっている。 しかし最近この分野における研究の進展は誠に目覚ましいものが あるので，クロム基合金の実用化も案外非常に近い将来に来るか あ知れない。このことはニッケル，コバルト等の重要資源に乏し いわが国にとっても等閑視できない問題である。

一文 献一

1) R. M. Parke, F.P. Bens, A.S. T. M. "Symp. Mater." p. 80 (1946).

2) A. H. Sully, "Chromium" (1945).

3) H. L. Gilbert, H. A. Johansen, R. G. Nelson, Trans. A. I. M.E. 197, 63 (1957).

4) H. L. Wain, F. Henderson, S. T. M. Johnstone, J.
Inst. Metals 83, 133 (1954).

5) R. R. Lloyd, et al, J. Electrochem. Soc. 97, 227 (1950).

6) M. C. Carosella, J. O. Mettler, A.S.M. "Ductile Chromium and its Alloys" p. 75 (1957).

7) H. T. Greenaway, J. Inst. Metals 83, 121 (1954).

8) B. M. Amonencko, Metal Physics and Metallography (Academy of Science, USSR) 7, 868 (1959).

9) L. L. Wyman, J. T. Sterling, "Ductile Chromium" A.S. M. p. 180 (1957).

10) R. A. Beall, G. Asai, A.S. M. "Ductile Chromium" p. 110 (1957).

11) F. Henderson, S. T. Quaass, H. L. Wain, J. Inst. Metals 83, 126 (1954).

12) 吉田, 大莛, 永田, 日本金属学会誌 24, 16 (1960).

13) A. H. Sully, “Chromium” p. 135 (1954).

14) D. J. Maykuth, et al, J. Electrochem. Soc. 102, 316 (1955).

15) H. L. Wain, et al, J. Inst. Metals 86, 281 (1958).

16）吉田，大庭，永田，未発表資料.

17) C. L. Faust, A.S.M. "Metals for Supersonic Aircraft and Missiles" p. 170 (1958).

18) D. J. Maykuth, R. I. Jaffee, A. S. M. "Ductile Chromium" 229 (1957).

19) G. R. Wilms, T.W. Rea, J.Inst Metals 87, 77(1958).

7 A) N:Ryan, J. Electrochem. Soc. 107, 397 (1960). 